\begin{tabular}{|l|l|l|}
\hline \multicolumn{2}{|c|}{ PublisherInfo } \\
\hline \hline PublisherName & $:$ & BioMed Central \\
\hline \hline PublisherLocation & $:$ & London \\
\hline \hline PublisherImprintName & $:$ & BioMed Central \\
\hline \hline
\end{tabular}

\title{
Plasma exchange for toxic epidermal necrolysis
}

\begin{tabular}{|l|l|l||}
\hline \multicolumn{2}{|c|}{ ArticleInfo } \\
\hline \hline ArticleID & $:$ & 4245 \\
\hline \hline ArticleDOI & $:$ & $10.1186 /$ ccf-2000-2461 \\
\hline \hline ArticleCitationID & $:$ & 2461 \\
\hline \hline ArticleSequenceNumber & $:$ & 33 \\
\hline \hline ArticleCategory & $:$ & Paper Report \\
\hline ArticleFirstPage & $:$ & 1 \\
\hline \hline ArticleLastPage & $:$ & 3 \\
\hline \hline & & RegistrationDate : 2000-1-12 \\
\hline ArticleHistory & $:$ & OnlineDate \\
\hline \hline ArticleCopyright & $:$ & Current Science Ltd2000-1-12 \\
\hline \hline ArticleGrants & $:$ & \\
\hline \hline ArticleContext & $:$ & 1305433 \\
\hline \hline
\end{tabular}




\section{Keywords}

Antibiotics, corticosteroids, plasma exchange, toxic epidermal necrolysis

\section{Comments}

TEN remains a rare skin disease which carries a high mortality (10-70\%) although this appears to be declining for unknown reasons. Consequently, it is almost impossible to compare treatments as part of a randomised controlled trial. This study provides evidence that PE offers no benefit in TEN.

Plasmapheresis is expensive with potential complications and at present its use can not be justified in TEN.

\section{Introduction}

Toxic epidermal necrolysis (TEN) is a rare skin disorder with a high mortality and is best treated in a burns ICU. Choice of therapy has focused on antibiotics, steroids and plasma exchange (PE), and this study evaluates the effectiveness of PE in one burns ICU.

\section{Aims}

Retrospective analysis of the effectiveness of PE in the treatment of TEN.

\section{Methods}

The outcome of eight patients treated with plasmapheresis for TEN over a 10 year period at the authors' ICU was compared to that found in two previous studies where PE was not utilised. (Khoo et al, Burns 1996, 4:275-278, Yarbrough et al, J Burn Care Rehabil 1996, 17:30-33)A median of six (1-8) PEs was given at an interval of 1-3 days. 


\section{Results}

Mean time from onset of TEN to complete re-epithelialisation was 27 days, which was longer than in the two previous studies where PE was not used. Mortality was similar in all studies.

\section{References}

1. Furubacke A, Berlin G, Anderson C, Sjoberg F: Lack of significant treatment effect of plasma exchange in the treatment of drug-induced toxic epidermal necrolysis?. Intensive Care Med. 2000, 25 : 1307-1310. 